\title{
BMC Biology turns five
}

\section{Elizabeth C Moylan, Matt J Hodgkinson, Maria Kowalczuk, Scott C Edmunds and Penelope A Webb*}

\author{
Address: BioMed Central, Middlesex House, 34-42 Cleveland St., London, W1T 4LB, UK \\ Email: Elizabeth C Moylan - elizabeth.moylan@biomedcentral.com; Matt J Hodgkinson - matt.hodgkinson@biomedcentral.com; \\ Maria Kowalczuk - maria.kowalczuk@biomedcentral.com; Scott C Edmunds - scott.edmunds@biomedcentral.com; \\ Penelope A Webb* - penny.webb@biomedcentral.com \\ * Corresponding author
}

Published: 16 December 2008

BMC Biology 2008, 6:53 doi:10.1/86/1741-7007-6-53
Received: II December 2008

Accepted: 16 December 2008

This article is available from: http://www.biomedcentral.com/I741-7007/6/53

(C) 2008 Moylan et al; licensee BioMed Central Ltd.

This is an Open Access article distributed under the terms of the Creative Commons Attribution License (http://creativecommons.org/licenses/by/2.0), which permits unrestricted use, distribution, and reproduction in any medium, provided the original work is properly cited.

BMC Biology launched in November 2003, under the stewardship of Peter Newmark and an international Editorial Board [1] as the flagship open access biology journal in the $B M C$ series, publishing research of general interest and special importance across the biological sciences. The aim was to bridge a gap between the premier journal, Journal of Biology [2] a home for exceptional research, and the established specialist titles in the $B M C$ series [3], such as $B M C$ Bioinformatics, by providing a more selective home for articles of broader interest. As BMC Biology's fifth birthday is upon us, it has secured its position within the $B M C$ series stable with an impressive debut impact factor of, appropriately, five!

We are absolutely delighted with our impact factor of five, but how was this achieved? One clear contributor to the impact factor is from the field of plant genomics, a paper by Christopher Town and colleagues (Complete reannotation of the Arabidopsis genome: methods, tools, protocols and the final release) [4] that has been cited over 50 times and is the most highly cited article published in BMC Biology. This is closely followed by two papers on species boundaries, from the research groups of Brian G Spratt (Fuzzy species among recombinogenic bacteria) [5] and James Mallet (Polyphyly and gene flow between non-sibling Heliconius species) [6]. Most of our published articles are from evolutionary biology, cell biology and neuroscience with genomics and developmental biology hot on their heels [7], although we welcome submissions across the full spectrum of biology.
Feedback from our authors makes it clear that they value the 'added extras' that publishing in BMC Biology brings. Faculty of 1000, a research service that highlights the most interesting papers published in the biological sciences [8], regularly features our research articles. Our sister journal, Journal of Biology, often publishes minireviews that put the work published in BMC Biology into a broader context, further widening the readership of the original research papers [2]. Most important, many of our research articles are press released [9] and generate considerable media interest. A notable example was a correspondence article by Martin Collinson on a video analysis of a Pileated Woodpecker that called into question the apparent sighting of the seemingly extinct Ivory-billed Woodpecker Campephilus principalis [10]. Finally, all articles are featured with a summary on the BMC Biology homepage, and many on the BioMed Central homepage.

It is gratifying to see that on the strength of its diverse and high-quality content over the last five years, BMC Biology has been ranked 219 of nearly 16,000 journals listed in the 2007 SCImago Journal Rank [11], a journal citation metric derived from Scopus [12]. This places BMC Biology in the top $1.5 \%$ of all journals. If you value the benefits brought by publishing in a high quality open access journal, with a dedicated editorial team, and a rigorous but fair and friendly peer review service, we look forward to receiving your next submission to BMC Biology.

\section{Acknowledgements}

We are grateful to Peter Newmark for steering the content of BMC Biology in the early years. 


\section{References}

I. BMC Biology Editorial Board [http://www.biomedcentral.com/ bmcbiol/edboard/]

2. Journal of Biology [http://jibiol.com/]

3. BMC series [http://www.biomedcentral.com/info/authors/bmc series]

4. Haas BJ, Wortman JR, Ronning CM, Hannick LI, Smith RK, Maiti R, Chan AP, Yu C, Farzad M, Wu D, White OR, Town CD: Complete reannotation of the Arabidopsis genome: methods, tools, protocols and the final release. BMC Biology 2005, 3:7.

5. Hanage WP, Fraser C, Spratt BG: Fuzzy species among recombinogenic bacteria. BMC Biology 2005, 3:6.

6. Bull V, Beltran M, Jiggins CD, McMillan WO, Bermingham E, Mallet J: Polyphyly and gene flow between non-sibling Heliconius species. BMC Biology 2006, 4:II.

7. BMC Biology subject areas [http://www.biomedcentral.com/bmc biol/subjects/]

8. Faculty of 1000 [http://www.fl 000 biology.com/]

9. Press releases [http://www.biomedcentral.com/info/presscenter/ pressreleases]

10. Collinson JM: Video analysis of the escape flight of Pileated Woodpecker Dryocopus pileatus: does the Ivory-billed Woodpecker Campephilus principalis persist in continental North America? BMC Biology 2007, 5:8.

II. SClmago Journal and Country Rank [http://www.scima goji.com/]

12. SClmago - a new source of journal metrics offering a wealth of free data on open access journals [http://blogs.openaccess central.com/blogs/bmcblog/entry/scimago a new source of]

Publish with Biomed Central and every scientist can read your work free of charge

"BioMed Central will be the most significant development for disseminating the results of biomedical research in our lifetime. "

Sir Paul Nurse, Cancer Research UK

Your research papers will be:

- available free of charge to the entire biomedical community

- peer reviewed and published immediately upon acceptance

- cited in PubMed and archived on PubMed Central

- yours - you keep the copyright 